\title{
The Religious Dimension of Skepticism
}

\author{
Rico Gutschmidt
}

\begin{abstract}
Philosophical skepticism, according to numerous influential accounts of it, is bound up with our failure or inability to adopt an "absolute" standpoint. Similarly, many religions speak of an "absolute" that also is beyond human reach. With this similarity in mind, I will develop what I take to be a religious dimension of skepticism. First, I will discuss the connection that Stanley Cavell draws between his reading of skepticism and the notions of God and original sin. I will then refer to William James's description of the religious experience of conversion and apply it to the transformative aspect of skepticism. Finally, I will argue with respect to mysticism and negative theology that the transformative experiences one can find in both skepticism and religion can be interpreted as yielding an experiential understanding of the finitude of the human condition.
\end{abstract}

There is a crack in everything.

That's how the light gets in.

Leonard Cohen, Anthem. ${ }^{1}$

\begin{abstract}
$\mathrm{I}^{\mathrm{N}}$ N CONTEMPORARY EPISTEMOLOGY, skepticism is usually construed as a paradox that needs to be resolved at the theoretical level. In its deepest and historically most influential forms, however, skepticism is best understood as a philosophical practice that leads to a transformation of the self. Based on his interpretation of Ludwig Wittgenstein, Stanley Cavell emphasizes this existential dimension of skepticism. In addition, he relates it to central religious notions, such as God, sin, and conversion, and recent work on Cavell highlights structural analogies between Cavell's philosophy and pivotal Christian doctrines.

Against this background, I aim in what follows to show that both philosophical skepticism and central aspects of religiosity attempt to grapple with the finitude of the human condition. Skepticism addresses our finitude when it refers to an absolute standpoint and claims that we cannot attain it, while many religious traditions posit some sort of "absolute" that is beyond human reach. In both cases, the opposition of the human and the absolute standpoints paints us as finite beings who do not and cannot attain a full grasp or control of their own existence. In this paper I will argue that both skepticism and religion can be interpreted as yielding an experience that is transformative in that it engenders an attitude of acknowledgment regarding our finitude. It is in this sense that I speak of a religious dimension of skepticism.
\end{abstract}

${ }^{1}$ Leonard Cohen, Poems and Songs (New York NY: Random House, 2011), p. 188. 
In the first part of the paper I discuss the connection that Cavell draws between his reading of skepticism and the notions of God and original sin. I argue that Cavell's references to these religious notions mirror structural analogies between the existential aspect of skepticism and central facets of theology. In addition, I refer to recent work on Cavell that argues that his interpretation of skepticism has important connections to theology. Proceeding from these arguments, I demonstrate that Cavell's notion of "acknowledgment" can be understood as referring to a stance of humility and equanimity that strongly resembles religious faith.

In the paper's second part I discuss William James's notion of a "common nucleus" of various forms of religiosity. This nucleus consists of an experience of conversion that includes a moment of self-surrender. I compare this experience with the transformative aspect of skepticism that can be found not only in Cavell but also in Pyrrhonism, Descartes, Hume, and above all Wittgenstein. Against this background, I argue that the religious and the skeptical transformative experiences both lead to the aforementioned humble attitude that acknowledges the fact that we cannot attain an absolute grasp or control of our own existence.

Finally, I show in the paper's third part that this is not just an analogy: the finitude that is acknowledged by the skeptical and the religious attitudes concerns the selfsame feature of the human condition. To this end I argue that we do not fully understand what the notion of the "absolute" is supposed to mean. Quietist readings of skepticism suggest that the notion of "absolute objectivity" is somehow confused or meaningless. Similarly, religious mysticism and negative theology claim that God is incomprehensible. Against this background I argue that both skepticism and religion can evoke epistemically transformative experiences that yield an experiential understanding of the finitude of the human condition.

\section{CAVELL ON THE SKEPTIC'S DESIRE AND ORIGINAL SIN}

A crucial feature of many accounts of modern skepticism is the quest for an "external" standpoint capable of affording us an absolutely objective perspective on ourselves and the world. In his influential paper "The Legacy of Skepticism," Thompson Clarke distinguishes between "plain" and "philosophical" questions against the background of this perspective: "The truth is, I think, that this simple quest for absolute objectivity drives us beyond the plain, moving us to philosophize."2 The concept of absolute objectivity that stands behind the drive to philosophize is then elucidated by referring to a standpoint that attempts to transform the world as a whole into an object of inquiry. This "philosophical" standpoint is external compared to the "plain" standpoint, which is situated within the world. As Clarke puts it, "Certain intuitive philosophers I respect say that in philosophizing we stand back and treat the world in its entirety as an object apart from us, whereas as plain men we are 'inside the 
world."'” 3 This is indeed a standard conception of objectivity. Bernard Williams calls it the "absolute conception of reality," Thomas Nagel the "view from nowhere."4

The perspective of an absolute standpoint can be and often has been interpreted as a "God's-eye" view. Accordingly, the Clarkean drive to philosophize can be interpreted as a longing for God's knowledge. As Cavell puts it: "I have sometimes referred to this aspiration as the human desire to have God's knowledge; hence, doubtless, to be God." 5 In his Claim of Reason, Cavell alludes to the Clarkean idea of "looking at the world as though it were another object," ${ }^{\prime \prime}$ which he then characterizes as "an expression of what I meant when I said that we want to know the world as we imagine God knows it." With respect to the external, absolutely objective standpoint, reinterpreted in religious terms, the Cavellian skeptic basically claims that we are not God or not in God's position and that this is a deficiency. For Cavell, the threat of skepticism arises from the belief that we should have access to the absolute standpoint and that we are lacking something of vital importance if we do not: "The beginning of skepticism is the insinuation of absence, of a line, or limitation, hence the creation of want, or desire; the creation, as I have put it, of the interpretation of metaphysical finitude as intellectual lack. (So speaks serpentine infinity.)" with which skepticism confronts us. To borrow Clarke's vocabulary, Cavell seems to be saying in passages like this that we should rest content with our position as plain men inside the world and that the drive to philosophize or the longing for an external standpoint pointlessly alienates us from this position. This interpretation, however, is misleading, as can be seen from Cavell's references to religion, to which I now turn.

Cavell alludes in this context not only to the biblical serpent but also to the doctrine of original sin. He claims that having absolute knowledge would imply that we were free of human nature and adds that " $[t]$ he doctrine of Original Sin can be taken as a reminder that, with one or rather with two exceptions humankind cannot be thus free." More directly: "Not finitude, but the denial of finitude is the mark of tragedy. This denial of finitude has also been taken as the mark of sin." ${ }^{10}$ The problem of epistemological skepticism does not, of course, exactly match the biblical story, which deals with knowledge of good and evil rather than with knowledge per se. However, Cavell also discusses the story of Eden and argues that it is about the

${ }^{3}$ Ibid. Clarke might be alluding to Cavell here. This is, at least, what Cavell indicates in the foreword of Stanley Cavell, The Claim of Reason (Oxford UK: Oxford Univ. Press, 1979), p. xxv.

${ }^{4}$ Cf. Bernard Williams, Descartes: The Project of Pure Enquiry (London UK: Routledge, 1978); Thomas Nagel, The View from Nowhere (Oxford UK: Oxford Univ. Press, 1986).

${ }^{5}$ Stanley Cavell, In Quest of the Ordinary: Lines of Skepticism and Romanticism (Chicago IL: Univ. of Chicago Press, 1988), p. 148.

${ }^{6}$ Cavell, Claim of Reason, p. 236.

${ }^{7}$ Ibid.

${ }^{8}$ Cavell, Quest of the Ordinary, p. 51, cf. also Espen Dahl, "Finitude and original sin: Cavell's contribution to theology," Modern Theology 27 (2011): 497-516 at p. 500.

${ }^{9}$ Cavell, Claim of Reason, p. 416.

${ }^{10}$ Ibid., p. 455. Cf. also Dahl, "Finitude and original sin," p. 506, and Espen Dahl, Stanley Cavell, Religion, and Continental Philosophy (Bloomington IN: Indiana Univ. Press, 2014), p. 9. 
denial of knowledge in general: "The explicit temptation of Eden is to knowledge, which above all means: to a denial that, as we stand, we know." ${ }^{11}$ Montaigne and Pascal also relate the urge for absolute knowledge that gives rise to skepticism to the doctrine of original $\sin ^{12}$ However, although Cavell alludes to the notion of "sin," he is generally hostile to Christianity. ${ }^{13}$ Even so, his claims about the human condition with respect to skepticism can be fruitfully linked to the Christian notion of the fallen state of mankind. ${ }^{14}$

Cavell argues that the desire for the external standpoint is not just an obsession of the skeptic, but an important part of our humanity: "I have claimed that skepticism is our philosophical access to the human wish to deny the conditions of humanity." ${ }^{15}$ Cavell stresses this over and over again and claims that the drive to transcend ourselves belongs to the human condition: "Nothing is more human than the wish to deny one's humanity." 16 "I mean to say that it is human, it is the human drive to transcend itself, make itself inhuman." ${ }^{17}$ As Espen Dahl points out, this human drive or, in religious terms, the human desire to become God or to have God's knowledge is also central to theological anthropology, so that "Cavell's understanding of scepticism ... has an intrinsic theological bearing that can enrich our understanding of finitude and sin." ${ }^{18}$ For Dahl, the crucial point is that Cavell does not claim that we should deny the human drive to be inhuman, but rather that we have to accept it as part of our humanity. ${ }^{19}$ As Cavell puts it: "Here my thought was that skepticism is a place, perhaps the central secular place, in which the human wish to deny the condition of human existence is expressed; and so long as the denial is essential to what we think of as the human, skepticism cannot, or must not, be denied." ${ }^{20}$ Following this line of thought, we are not just to rest content with our position as plain men inside the world. Instead, although the wish to deny this position is indeed a

${ }^{11}$ Cavell, Quest of the Ordinary, p. 49.

${ }^{12} \mathrm{Cf}$. José R. Maia Neto, The Christianization of Pyrrhonism. Scepticism and Faith in Pascal, Kierkegaard, and Shestov (Dordrecht: Springer, 1995), pp. 17, 53. Stephen Mulhall refers in more general terms to the human "desire to deny the human" and to the "prideful human craving to be God" and analyzes with respect to Nietzsche, Heidegger, and Wittgenstein corresponding "philosophical myths of the fall," cf. Stephen Mulhall, Philosophical Myths of the Fall (Princeton NJ: Princeton Univ. Press, 2005), pp. 94, 120.

${ }^{13} \mathrm{Cf}$., for example, Stephen Mulhall, Stanley Cavell: Philosophy's Recounting of the Ordinary (Oxford UK: Oxford Univ. Press, 1998), pp. 286-92.

${ }^{14}$ The relation of Cavell's reading of skepticism to Christianity is analyzed, for example, in Dahl, "Finitude and Original Sin"; Dahl, Stanley Cavell; Mulhall, Stanley Cavell, Ch. 12; Fergus Kerr, Immortal Longings: Versions of Transcending Humanity (London UK: SPCK, 1997), pp. 123-31; Rick A. Furtak, "Skepticism and Perceptual Faith: Henry David Thoreau and Stanley Cavell on Seeing and Believing," Transactions of the Charles S. Peirce Society 43 (2007): 542-61; Judith E. Tonning, "Acknowledging a Hidden God: A Theological Critique of Stanley Cavell," Heythrop Journal 48 (2007): 384-405; and Ludger H. Viefhues-Bailey, Beyond the Philosopher's Fear: A Cavellian Reading of Gender, Origin, and Religion in Modern Skepticism (Burlington VT: Ashgate, 2007).

${ }^{15}$ Cavell, Quest of the Ordinary, p. 138.

${ }^{16}$ Cavell, Claim of Reason, p. 109.

${ }^{17}$ Stanley Cavell, This New Yet Unapproachable America: Lectures after Emerson after Wittgenstein (Albuquerque NM: Living Batch Press, 1989), p. 57.

${ }^{18}$ Dahl, "Finitude and Original Sin," p. 498-99.

${ }^{19}$ Ibid., pp. 502-03; 512.

${ }^{20}$ Cavell, Quest of the Ordinary, p. 5. 
form of alienation from our humanity, it is still, somewhat paradoxically, a crucial part of the human condition. With reference to the just-quoted passage from Cavell, Dahl points out that the religious equivalent of skepticism as the "secular place" of this aspect of the human condition is the notion of $\sin .{ }^{21}$ Cavell claims that the skeptic's longing for an external standpoint or the human drive to transcend itself is part of our humanity. Similarly, theology claims that we cannot get rid of the sinful desire to become God. Accordingly, Dahl argues that Cavell analyzes the "intricate dynamic between finitude and sin" and thereby yields a "specific contribution to theology's understanding of original sin."'22

This, however, is not yet the full story. On the one hand, we are supposed to accept this part of our humanity. On the other hand, we cannot, in the end, according to Cavell, attain the external standpoint, and, obviously, we are not God. The adamant longing for the absolute is unfulfillable. Thus, the question arises how we should deal with this longing. In this context, Cavell speaks of a recovery from skepticism that he also relates to the notion of sin: "But in all philosophical seriousness, a recovery from what? Philosophy cannot say sin. Let us speak of a recovery from skepticism. This means, as said, from a drive to the inhuman." ${ }^{23}$ In a nutshell, for Cavell, a recovery from skepticism can be gained only through its reinterpretation. The usual interpretation of skepticism, according to Cavell, is that "we think skepticism must mean that we cannot know the world exists, and hence that perhaps there isn't one." ${ }^{24}$ Against that, Cavell reinterprets skepticism in a way that can be summarized by the claim that "what skepticism suggests is that since we cannot know the world exists, its presentness to us cannot be a function of knowing. The world is to be accepted; as the presentness of other minds is not to be known, but acknowledged." ${ }^{25}$ This, basically, is what Cavell calls the "truth of skepticism" (or, alternatively, the "moral of skepticism"): "namely, that the human creature's basis in the world as a whole, its relation to the world as such, is not that of knowing, anyway not what we think of as knowing." ${ }^{26}$

Now, this acceptance or acknowledgment should not be understood as bringing us back to where we were before we got disturbed by skepticism. We do not just end up being plain men inside the world again, now no longer bothered about the supposed need for an objective foundation of our knowledge. Instead, I think that the attitude of acceptance or acknowledgment marks an important difference: It is only through the experience of skepticism (or, as I will argue in the third part, through some sort of religious experience) that we become fully aware of the finitude of the human condition. Only through experiencing the failure of the attempt to step outside the plain do we understand what it means to be plain. Only through the drive to be inhuman do we understand what it means to be human.

\footnotetext{
${ }^{21}$ Dahl, "Finitude and Original Sin," p. 498.

${ }^{22}$ Dahl, "Finitude and Original Sin," p. 512, cf. also Dahl, Stanley Cavell, p. 14.

${ }^{23}$ Cavell, Quest of the Ordinary, p. 26.

${ }^{24}$ Stanley Cavell, Must We Mean What We Say? A Book of Essays (New York NY: Scribner, 1969), p. 324.

${ }^{25}$ Ibid.

${ }^{26}$ Cavell, Claim of Reason, p. 241, cf. also Cavell, Quest of the Ordinary, p. 109.
} 
Furthermore, I think that the attitude of acceptance or acknowledgment can be interpreted as a stance of humility and equanimity that acknowledges the fact that we do not and cannot attain an absolute grasp or control of our own existence. ${ }^{27}$ Without the skeptical experience, without the perpetual temptation of sin, we do not realize that our existence rests upon a basic form of confidence all the time. This link between skepticism and the temptation of sin is one of the crucial steps of my argument about the religious dimension of skepticism. It was claimed that Cavell's attitude of acknowledgment constitutes a "fundamentally religious attitude" 28 and that the corresponding "trust in an objective uncertainty might be described as the essence of faith." ${ }^{29}$ At the very end of the first part of his Claim of Reason, Cavell explicitly acknowledges that we might have the impulse to invoke faith when reflecting on our real relation to the world, but he then asks a series of questions that seem to imply that we cannot really project the grammar of "faith" into the context of skepticism. ${ }^{30}$ However, he nonetheless points to a religious dimension of his reading of skepticism when he speaks of the necessity "to rid us of the prideful craving to be God-I mean to rid us of it, not to replace it with a despair at our finitude. ${ }^{\prime 31}$ Since the attitude of acknowledgment can be interpreted as a way to overcome the craving to be God without falling into despair, I think that there is a strong link between this attitude and faith. Elsewhere, Cavell refers to Luther, according to whom "we cannot know God but must have faith." 32 This shift from the longing for knowledge of God to faith strongly resembles Cavell's shift from the skeptic's longing for absolute knowledge to an attitude of acknowledgment or reliance. Indeed, for Luther, faith (fides) is interdependent with trust (fiducia).

The link between the Cavellian attitude of acknowledgment and the religious attitude of faith has another important aspect. Since for Cavell and for theology the longing for an external standpoint or for God's knowledge belongs to the human condition, neither of these attitudes yield a stable position. In theological terms, we remain sinners even in the attitude of faith. We are, following a statement of Luther, simul iustus et peccator. With respect to Cavell and theology, Espen Dahl speaks of an anthropology of finitude, which "depicts humanity as constantly oscillating between skepticism and acknowledgment. ... In Cavell's perspective, this ... amounts to our finding us, uncannily, both at home and not at home within the ordinary."${ }^{\prime 33}$ This "perpetual instability" 34 is what Cavell calls the "threat of skepticism, which The Claim of Reason claims to be humanly definitive." ${ }^{35}$ In religious terms, this is

\footnotetext{
${ }^{27}$ Similarly, Furtak argues that Cavell's attitude of acceptance can be interpreted as an attitude of basic trust. Cf. Furtak, p. 545.

${ }^{28}$ Asja Szafraniec, "Inheriting the Wound: Religion and Philosophy in Stanley Cavell" in Religion: Beyond a Concept, ed. Hent de Vries (New York NY: Fordham Univ. Press, 2008), pp. 368-79 at p. 372.

${ }^{29}$ Furtak, p. 546.

${ }^{30}$ Cavell, Claim of Reason, p. 243. I thank Stephen Mulhall for reminding me of this passage.

${ }^{31}$ Cavell, Claim of Reason, p. 237.

${ }^{32}$ Cavell, Must We Mean What We Say? p. 324.

${ }^{33}$ Dahl, Stanley Cavell, p. 13.

${ }^{34}$ Cavell, Quest of the Ordinary, p. 148.

${ }^{35}$ Ibid.
} 
to say that we cannot overcome the temptation of sin. In this respect, Dahl argues that "what makes Cavell's implied understanding of sin particularly profound is his conviction that the voice of temptation - the sceptic's wish, one might say — cannot be definitively refuted." ${ }^{36}$ Although the longing for the absolute is unfulfillable and can be appeased through an attitude of acknowledgment or faith, we do not get over this longing once and for all. Instead, Dahl points out that "this voice of temptation must in the end also be acknowledged and accepted as part of the human." 37 This, obviously, is a striking analogy between Cavell's reading of skepticism and the theological analysis of the sinfulness of the human condition.

Moreover, I think that Cavell's reading of skepticism and the theological notion of the fallen state of mankind can both be interpreted as pointing to the fact that our self-understanding as "plain" beings hinges on the unfulfillable longing for the absolute, and is, in other words, dependent on the perpetual temptation of sin. On this reading, we can acknowledge the plainness of the human condition only through an unstable position. As I have argued above, we understand what it means to be "plain" only through the unfulfillable yet unavoidable — and thus perpetual — attempt to step outside the plain. This interpretation corresponds to the fact that neither the Cavellian attitude of acknowledgment nor the religious attitude of faith provide a stable position. Against this background, I will argue in the following parts of this paper that the religious dimension of skepticism involves more than a structural analogy. ${ }^{38}$

\section{RELIGIOUS CONVERSION AND SKEPTICAL TRANSFORMATION}

In his Varieties of Religious Experience, William James surveys many forms of religiosity and asks if there is a "common nucleus" 39 that they all share. His answer is "yes":

The warring gods and formulas of the various religions do indeed cancel each other, but there is a certain uniform deliverance in which religions all appear to meet. It consists of two parts:

1. An uneasiness; and

2. Its solution. ${ }^{40}$

${ }^{36}$ Dahl, "Finitude and Original Sin," p. 502.

${ }^{37}$ Ibid., pp. 502-03, cf. also Dahl, Stanley Cavell, p. 80.

${ }^{38}$ While Stephen Mulhall speaks of "structural analogies between Cavellian and Christian thought" (Mulhall, Stanley Cavell, p. 296), Espen Dahl suggests "that there is more than a structural analogy between theological and philosophical praxis at this point" (Dahl, "Finitude and Original Sin," p. 503). Dahl points to Cavell's references to Adolf von Harnack and Karl Barth (ibid). In addition, Cavell explicitly acknowledges religious influences on his approach as, for example, Kierkegaard's knight of faith in Fear and Trembling, cf. Cavell, This New Yet Unapproachable America, p. 39. Not least, Cavell describes the transformative aspect of his philosophical agenda in terms of a conversion: "And for grown-ups this is not natural growth, but change. Conversion is a turning of our natural reactions" (Cavell, Claim of Reason, p. 125).

${ }^{39}$ William James, Varieties of Religious Experience: A Study in Human Nature (London UK: Routledge, 2002), p. 392.

${ }^{40} \mathrm{Ibid}$. 
He describes the uneasiness as "a sense that there is something wrong about us as we naturally stand." 41 The solution of the uneasiness is described as "a sense that we are saved from the wrongness by making proper connection with the higher powers." 42 Hence, at the center of religiosity, according to James, there lies a personal transformation or, as James puts it, a "change of personal centre" with respect to "higher powers." 43

In the lectures on conversion James describes the personal transformation in more detail. ${ }^{44} \mathrm{He}$ refers to a habitual center of a person's personal energy and describes religious conversion in terms of a transformation with respect to this center. ${ }^{45}$ In particular, this transformation is achieved through a form of self-surrender that he describes as a crisis of self-surrender ${ }^{46}$ since it starts with the abovementioned uneasiness. While there are many forms of uneasiness and many ways of sensing that there is something wrong with us, James focuses on what he calls "objective forms of melancholy." These are forms of uneasiness "in which the lack of rational meaning of the universe, and of life anyhow, is the burden that weighs upon one. ${ }^{" 47}$ According to James, such melancholy is cured in a religious context by a transformation of the personal center of energy that is achieved through self-surrender, which James describes as "the throwing of our conscious selves upon the mercy of powers which, whatever they may be, . . . make for our redemption." ${ }^{48}$ Finally, James argues that the result of this transformation is a state of mind that "overcomes temperamental melancholy and imparts endurance to the Subject, or a zest, or a meaning, or an enchantment and glory to the common objects of life." ${ }^{49}$ James refers to this state of mind as a "faith state." ${ }^{50}$ All in all, for James, this crisis of self-surrender is "the vital turning-point of the religious life." the abovementioned solution of an uneasiness, this is, in James's account, the central part of religiosity itself.

Now, while James describes objective forms of melancholy in terms of a lack of meaning, the skeptic's unfulfillable longing for an external standpoint can also, according to Cavell, lead to an uneasiness or to a sense that there is something wrong with us. As a matter of fact, this is how Cavell introduces the "reasonableness of doubt." 52 Against Austin's argument that we do not have reason for radical skeptical doubt, he argues that "the philosopher begins his investigation with the sense that, as I am expressing it, something is, or may be amiss with knowledge as a whole." 53

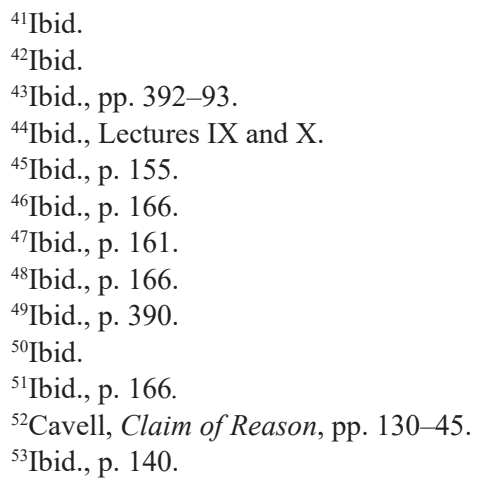


More precisely, for Cavell, skepticism starts with "an experience or sense that one may know nothing about the real world." "54 This fits into Cavell's abovementioned reading of skepticism as the insinuation of absence or limitation, which implies uneasiness, as he points out: "No one wants to be a skeptic; to be gripped by its threat is to wish to overcome it."

Moreover, according to Cavell, the skeptical threat renders the world uncanny, ${ }^{56}$ and the solution of the skeptical uneasiness is achieved through a personal transformation, namely, through the abovementioned transformation toward an attitude of acknowledgment. However, Cavell does not spell out the details of this transformation. Thus, I want to suggest here that it is best understood as a form of self-surrender too, namely, as the abandoning of the longing for an external standpoint. Of course, this is not a straightforward procedure. As Dahl points out with respect to Cavell and Wittgenstein, "the acknowledgment of human limitation ... seems hard to achieve." ${ }^{\prime 7}$ In Cavell's words: "I mean, acknowledging that the world exists, that you know for yourself that it is yours, is not so clear a process. ${ }^{158}$ Once the skeptic has been gripped by the desire for an external standpoint, the contrasting insight into the finitude of his position, Cavell argues, is "as simple as it is difficult, and as difficult as it is (and because it is) terrifying." ${ }^{59}$ Accordingly, the Cavellian transformation really is a crisis of self-surrender. It is not about throwing ourselves upon the mercy of "higher powers"; rather, as I have argued above, it leads to a reliant attitude that acknowledges the fact that we cannot attain a full grasp or control of our own existence. For the skeptic, this insecure situation appears to be terrifying, but as a result of a crisis of self-surrender it will be accepted through the attitude of acknowledgment.

Again, this attitude is not a stable position. Instead, it is challenged over and over again by the wish to overcome the terrifying finitude of the human condition through the adoption of an absolute standpoint. Cavell does not refute skepticism, but reinterprets it with respect to its existential dimension. The skeptical threat (according to which things might be completely different from how they appear to us to be) remains in force. Moreover, we are supposed to acknowledge the fact that our existence indeed rests on a basic form of confidence all the time. On my reading, however, the moment of self-surrender with respect to the wish to achieve control of our existence can lead to an abiding stance of humility and equanimity. Even though this attitude is not as glorious as the "faith state" that James describes, it is still a positive, not a despairing, attitude, one that can thus, with respect to James, be understood as a secular equivalent of faith. The aspect of equanimity is crucial, though, since neither faith nor the attitude of acknowledgment yields a stable position. I pointed out already that Luther linked faith to trust. In addition,

\footnotetext{
${ }^{54}$ Ibid.

${ }^{55}$ Cavell, Quest of the Ordinary, p. 44.

${ }^{56}$ Ibid., p. 100.

${ }^{57}$ Dahl, Stanley Cavell, p. 66.

${ }^{58}$ Cavell, Quest of the Ordinary, p. 85.

${ }^{59}$ Cavell, Must We Mean What We Say? p. 52.
} 
Paul Tillich, in his The Courage to Be, refers to Luther and links faith not just to an attitude of trust, but also to an attitude of courage, more precisely to an attitude of "courage of confidence." ${ }^{\prime 60}$ Accordingly, I think that both faith and the Cavellian attitude of acceptance or acknowledgment are best understood as a reliant stance of humility and equanimity in the face of our unstable position with respect to the finitude of the human condition.

Against the background of Cavell's reading of the skeptical transformation, I will now briefly explore the religious dimension of some specific manifestations of skepticism. To begin with, ancient skepticism has a strong existential dimension, particularly in the Pyrrhonian school. While most of the schools of ancient philosophy were seeking a transformation towards the happiness of wisdom with the help of knowledge, for Pyrrhonists an equivalent transformation is achieved in the very moment of the failure of the attempt to gain philosophical knowledge.

According to Sextus Empiricus, Pyrrhonian skepticism is a method or an ability to challenge philosophical claims or arguments with equally credible counter-claims or counter-arguments with the aim of inducing the equipollence (isostheneia) of the opposing positions. ${ }^{61}$ This leads to suspension of judgment (epochê), which is then followed by a state of equanimity (ataraxia). ${ }^{62}$ This is, of course, a very coarse-grained representation of Pyrrhonism, and I will neither discuss all the details nor refer to the enormous debate surrounding them. ${ }^{63}$ According to Sextus, the uncertainty that precedes philosophical inquiry is a troubling experience. ${ }^{64} \mathrm{On}$ my reading, the result of encountering equipollence represents a failure to resolve this troubledness or uneasiness. Finally, however, this uneasiness is solved by a form of surrender, namely, by suspension of judgment, which, in the end, leads to a transformation of one's attitude from troubledness to equanimity. This strongly resembles the structure of a religious conversion in James's sense. It has often been pointed out that there are strong analogies between Pyrrho's account of skepticism and Indian Buddhism. ${ }^{65}$ Not least, as a result of the skeptical transformation, Pyr-

${ }^{60}$ Paul Tillich, The Courage to Be (New Haven CT: Yale Univ. Press, 2000), pp. 160-61.

${ }^{61} \mathrm{PH}$ I 8-10. Here and in what follows, PH is used as shorthand for Sextus Empiricus, Outlines of Pyrrhonism (Pyrrhōneioi Hupotupōseis), see, e.g., Sextus Empiricus, Outlines of Scepticism, trans. Julia Annas and Jonathan Barnes (Cambridge UK: Cambridge Univ. Press, 2000).

${ }^{62} \mathrm{Ibid}$. The standard translation of ataraxia is "tranquility." However, following Roger E. Eichorn, Philosophy and Everyday Life: Thompson Clarke and the Legacy of Skepticism (Chicago IL: Univ. of Chicago: Dissertation, 2019), I think that "equanimity" is more adequate. Eichorn refers to Adrian Kuzminski, who argues that ataraxia was "originally a military term indicating calm by soldiers under attack," Adrian Kuzminski, Pyrrhonism: How the Ancient Greeks Reinvented Buddhism (Lanham MD: Lexington, 2008), p. 2.

${ }^{63}$ Cf., e.g., Alan Bailey, Sextus Empiricus and Pyrrhonean Scepticism (Oxford UK: Oxford Univ. Press, 2002); Diego E. Machuca, ed., Pyrrhonism in Ancient, Modern, and Contemporary Philosophy (Dordrecht: Springer, 2011); and Katja Vogt, Skepsis und Lebenspraxis: Das pyrrhonische Leben ohne Meinungen (München, Freiburg: Alber, 2015).

${ }^{64} \mathrm{PH}$ I 12.

${ }^{65}$ Cf. Kuzminski, Pyrrhonism; Everard Flintoff, "Pyrrho and India," Phronesis 25 (1980): 88-108; Thomas McEvilley, "Pyrrhonism and Mādhyamika," Philosophy East and West 32 (1982): 3-35; Hilmar Schmiedl-Neuburg, "Pyrrhonische Skepsis und die Indische Philosophie," Zeitschrift für Kulturphilosophie (2014): 343-65; and Christopher I. Beckwith, Greek Buddha: Pyrrho's Encounter with Early Buddhism in Central Asia (Princeton NJ: Princeton Univ. Press, 2015). 
rhonians "live in accordance with everyday observances" $" 66$ and do not make any statements that are supposed to describe things as they really are or as they are by nature as opposed to how they appear to us to be ${ }^{67}$ In other words, they acknowledge the fact that their everyday beliefs are not known to be objectively justified. ${ }^{68}$ Thus, the Pyrrhonian acquiescence in everyday life can be interpreted as a reliant attitude of humility and equanimity that thereby resembles the attitude of faith. In addition, as in Cavell's reading of skepticism, this is not a stable or final position.

For Markus Gabriel, this is a shortcoming of the Pyrrhonian school. Pyrrhonism sets out to cure us of an uneasy position by inducing the state of ataraxia, but Gabriel rightly points out that this is realized only through a therapy that does not come to an end. ${ }^{69}$ As a matter of fact, Sextus explicitly argues that Pyrrhonian skepticism does not entail holding the claim or position that philosophical knowledge, i.e., objective justification, is impossible to attain. Sextus attributes this claim to Academic skepticism and states that, in contrast, the Pyrrhonian skeptics "are still investigating." ${ }^{70}$ Hence, the problem of objective justification is not ultimately solved by suspension of judgment. Rather, Pyrrhonists also suspend judgment on the very question of whether objective knowledge can be attained. They put their own skepticism into question, which indeed does not yield a stable position. For Gabriel, this is an inconsistency of Pyrrhonism. ${ }^{71}$

Against that, I think that it mirrors the human condition. We simply are in an unstable position. The never-ending desire for an external standpoint is part of our humanity; we are both at home and not at home within the ordinary. In Christian terms, this is the doctrine of original sin; in philosophical terms, this is the lesson of Pyrrhonian skepticism.

In contrast to the skeptical method of the Pyrrhonian school, modern skepticism is not explicitly related to a way of life. Rather, it is construed as a form of philosophical thesis, either to be affirmed or to be denied. It still has a strong experiential aspect, however. Descartes, for example, refers at the beginning of his Second Meditation to the ground-shaking effect of his skeptical enquiry:

So serious are the doubts into which I have been thrown as a result of yesterday's meditation that I can neither put them out of my mind nor see any way of resolving them. It feels as if I have fallen unexpectedly into a deep whirlpool which tumbles me around so that I can neither stand on the bottom nor swim up to the top. ${ }^{72}$

${ }^{66} \mathrm{PH}$ I 23.

${ }^{67} \mathrm{PH}$ I 4.

${ }^{68}$ Cf., e.g., Roger E. Eichorn, "How (Not) To Read Sextus Empiricus," Ancient Philosophy 34 (2014): 121-49 at p. 130.

${ }^{69}$ Markus Gabriel, Skeptizismus und Idealismus in der Antike (Frankfurt a.M.: Suhrkamp, 2009), pp. $144,179$.

${ }^{70} \mathrm{PH}$ I 3.

${ }^{71}$ Gabriel, pp. 170, 179.

${ }^{72}$ René Descartes, Meditations on First Philosophy, ed. John Cottingham (Cambridge UK: Cambridge Univ. Press, 1996), p. 16. 
This certainly describes a strong uneasiness. It is resolved by Descartes not through a personal transformation, but rather through a theoretical refutation of skepticism. But still, even though this refutation is supposed to be achieved by reason alone, in the end it relies on a God that does not deceive: "although the ability to deceive appears to be an indication of cleverness or power, the will to deceive is undoubtedly evidence of malice or weakness, and so cannot apply to God." ${ }^{.73}$ This is not exactly self-surrender in James's sense, but Descartes's refutation does explicitly depend on "higher powers," namely, on the God of the ontological argument. Thus, Descartes's treatment of skepticism leaves us with a stance of trusting in something that is beyond our control, which resembles James's faith state.

In a way, David Hume's treatment of skepticism can also be interpreted along these lines. In the last section of Book I of his Treatise of Human Nature, Hume famously depicts a very strong form of uneasiness as a result of his engagement with the skeptical threat:

The intense view of these manifold contradictions and imperfections in human reason has so wrought upon me, and heated my brain, that I am ready to reject all belief and reasoning, and can look upon no opinion even as more probable or likely than another. Where am I, or what? From what causes do I derive my existence, and to what condition shall I return? Whose favour shall I court, and whose anger must I dread? What beings surround me? and on whom have I any influence, or who have any influence on me? I am confounded with all these questions, and begin to fancy myself in the most deplorable condition imaginable, inviron'd with the deepest darkness, and utterly depriv'd of the use of every member and faculty. ${ }^{74}$

This is an impressive description of the terrifying aspect of skepticism. Although this aspect is not exactly the objective form of melancholy that James discusses, it surely represents a strong uneasiness that needs to be resolved. Hume describes not so much a lack of meaning, but an equally strong disturbance that also results from philosophical, and thus "objective" and not just personal, considerations. Not least, Hume explicitly refers to this state of mind as "philosophical melancholy and delirium." 75 For Hume as for James, the cure of this melancholy consists in a personal transformation that can be interpreted as a form of self-surrender. Hume explicitly claims that "reason is incapable of dispelling these clouds." ${ }^{.76} \mathrm{But}$, instead of throwing reason upon the mercy of higher powers, he refers to "nature herself," which relaxes "this bent of mind." his study and returns to everyday life: "I dine, I play a game of back-gammon, I converse, and am merry with my friends." ${ }^{178}$ From this everyday perspective, the

${ }^{73}$ Ibid., p. 37.

${ }^{74}$ David Hume, A Treatise of Human Nature, ed. David F. Norton and Mary J. Norton (Oxford UK: Oxford Univ. Press, 2007), p. 175.

${ }^{75}$ Ibid.

${ }^{76}$ Ibid.

${ }^{77}$ Ibid.

${ }^{78} \mathrm{Ibid}$. 
skeptical problems "appear so cold, and strain'd, and ridiculous, that I cannot find in my heart to enter into them any farther." ${ }^{" 79}$

Of course, this sounds more like a retreat from skepticism. I think though that it can be interpreted as a real transformation. On my reading, Hume treats skepticism in terms of an uneasiness and its solution through a form of self-surrender, not with respect to "higher powers," but with respect to "nature herself," which also represents an entity that is beyond our control. As we have seen with Sextus and Descartes, this does not yield a stable position. Even though Hume is able to laugh about the skeptical threat when he leaves his study ${ }^{80}$ he still argues that skepticism demonstrates "the whimsical condition of mankind, who must act and reason and believe; though they are not able, by their most diligent enquiry, to satisfy themselves concerning the foundation of these operations, or to remove the objections, which may be raised against them." ${ }^{81}$ On my reading, Hume's entanglement with everyday life and his concurrent acknowledgment of the whimsical condition of humankind represents the unstable position of the reliant stance of humility and equanimity that I discussed above with respect to Cavell.

Finally, Cavell's interpretation of skepticism is highly influenced by his reading of Wittgenstein. In particular, the return to the ordinary is an important aspect of Wittgenstein's philosophy, which has often been linked to Pyrrhonism. ${ }^{82}$ In addition, the concept of personal transformation is crucial to Wittgenstein, as has been established in the various resolute and therapeutic readings. ${ }^{83}$ Above all, Wittgenstein shows, particularly in On Certainty, that we cannot justify our fundamental beliefs. In this late major work, Wittgenstein argues that the process of justification always comes to an end, but does not yield an ultimate justification. ${ }^{84}$ Instead, he interprets our fundamental beliefs as hinges that are stable only relative to our epistemic practices; we rely on these hinge propositions without being able to secure them. ${ }^{85}$

Duncan Pritchard points out that Wittgenstein's work on skepticism was influenced by John Henry Newman, whom Wittgenstein mentions in the very first passage of On Certainty. ${ }^{86}$ Such reference is unusual in Wittgenstein's work, and Pritchard

${ }^{79}$ Ibid.

${ }^{80}$ David Hume, An Enquiry concerning Human Understanding, ed. Peter Millican (Oxford UK: Oxford Univ. Press, 2007), p. 117.

${ }^{81}$ Ibid.

${ }^{82}$ Cf., e.g., Richard A. Watson, "Sextus and Wittgenstein," Southern Journal of Philosophy 7 (1969): 229-36; Robert J. Fogelin, Wittgenstein (London UK: Routledge and Kegan Paul, 1987); Bob Plant, "The End(s) of Philosophy: Rhetoric, Therapeia and Wittgenstein's Pyrrhonism," Philosophical Investigations 27 (2004): 222-57; Hans Sluga, "Wittgenstein and Pyrrhonism" in Pyrrhonian Skepticism, ed. Walter Sinnott-Armstrong (Oxford UK: Oxford Univ. Press, 2004), pp. 99-117; and Duncan Pritchard, "Wittgensteinian Pyrrhonism" in Pyrrhonism in Ancient, Modern, and Contemporary Philosophy, ed. Diego E. Machuca (Dordrecht: Springer, 2011), pp. 193-202.

${ }^{83} \mathrm{Cf}$. Alice Crary, "Introduction" in The New Wittgenstein, ed. Alice Crary and Rupert Read (London UK: Routledge, 2000), pp. 1-18.

${ }^{84}$ Ludwig Wittgenstein, On Certainty, trans. Denis Paul and G.E.M. Anscombe (Oxford UK: Basil Blackwell, 1969), §§192, 253.

${ }^{85}$ Ibid., $\S \S 144,248,341-43$.

${ }^{86}$ Ibid., §1; Duncan Pritchard, "Wittgensteinian Quasi-Fideism," Oxford Studies in the Philosophy of Religion 4 (2011): 145-59 at p. 159. 
claims with respect to the notion of "hinge propositions" that Wittgenstein was influenced by Newman's point that "rational belief in general presupposes certain commitments which are by their nature not rationally grounded, his ultimate point being that religious belief was no less rational than, say, scientific belief on this score." ${ }^{87}$ Hence, according to Pritchard, Wittgenstein's argument that we cannot justify our fundamental beliefs has a religious background. ${ }^{88}$

Looking beyond Newman, Wittgenstein's notion of certainty strongly resembles Luther's way of linking faith to the notion of certitudo as opposed to the notion of securitas. The second notion represents the human desire to secure our beliefs on our own, while the first represents an attitude of trust that acknowledges the fact that we cannot attain full control of our existence. As I mentioned in the first part, Luther takes faith to be a matter of trust and thus of certitudo, not of securitas. Similarly, the main point of On Certainty is that we cannot secure our fundamental beliefs. Without being aware of it, our existence always already rests upon a basic form of confidence, and the goal of Wittgenstein's transformative philosophy is to bring this to mind: "The difficulty is to realize the groundlessness of our believing." $" 19$ a nutshell, on my reading, Wittgenstein does not simply aim at the dissolution of philosophical problems. He treats philosophical problems in such a way that they transform us from our natural state that takes our fundamental beliefs to be objectively justified toward a faith state that acknowledges the groundlessness of these beliefs.$^{90}$ This resembles James's description of conversion, and, indeed, Wittgenstein was familiar with his Varieties of Religious Experience and appreciated this work. ${ }^{91}$

There is another point in On Certainty where Wittgenstein indicates that this transformation has a religious dimension. Through the text, he often refers to examples from everyday contexts. One example deals with a shopkeeper who checks his apples: "If the shopkeeper wanted to investigate each of his apples without any reason, for the sake of being certain about everything, why doesn't he have to investigate the investigation?"'92 The investigation of the investigation leads to a regress that, in the context of On Certainty, demonstrates the groundlessness of the belief that everything is fine with the apples. So why does the shopkeeper not have to investigate the investigation? How can we defeat the skeptical threat? How

${ }^{87}$ Ibid.

${ }^{88} \mathrm{Cf}$. also Duncan Pritchard, "Wittgenstein on Faith and Reason: The Influence of Newman" in God, Truth and Other Enigmas, ed. Miroslaw Szatkowski (Berlin: De Gruyter, 2015), pp. 141-64. The religious dimension of Wittgenstein's work can be found more explicitly in his "Lecture on Ethics" and in the Remarks on Frazer's Golden Bough.

${ }^{89}$ Wittgenstein, On Certainty, $\S 166$.

${ }^{90} \mathrm{Cf}$. Rico Gutschmidt, "Beyond Quietism: Transformative Experience in Pyrrhonism and Wittgenstein," International Journal for the Study of Skepticism 10 (2020): 105-128. In more general terms, the transformative aspect of Wittgenstein's philosophy is highlighted by Ray Monk: "Wittgenstein's remark about philosophy - that it 'leaves everything as it is' - is often quoted. But it is less often realized that, in seeking to change nothing but the way we look at things, Wittgenstein was attempting to change everything," Ray Monk, Wittgenstein. The Duty of Genius (London UK: Vintage, 1990), p. 533.

${ }^{91}$ Cf., e.g., Russell B. Goodman, Wittgenstein and William James (Cambridge UK: Cambridge Univ. Press, 2002), pp. 11-12.

${ }^{92}$ Wittgenstein, On Certainty, $\S 459$. 
can we nullify the human desire for an external standpoint? For Sextus, we can suspend judgment on the real nature of the apples and just deal with them as they appear to us. For Cavell, it is the attitude of acknowledgment that accepts the apples as part of our everyday life. Wittgenstein points out that we do believe in the plain existence of the apples all the time, but that this belief is groundless. Beyond Sextus and Cavell, Wittgenstein relates this form of belief explicitly to the attitude of faith. In the everyday context of the shopkeeper, Wittgenstein not only questions why he does not have to investigate the investigation but also asks: "And can one talk of belief here (I mean belief as in 'religious belief,' not surmise)?"'93 I think that one can. As I argued in the first part, the attitude of acknowledgment can be interpreted as a religious attitude. Wittgenstein is not saying that such transformation actually happens to the shopkeeper, but should the shopkeeper stumble upon the skeptical abyss of the investigation of the investigation, he can solve the corresponding uneasiness by the self-surrender of accepting the groundlessness of his belief in the apples' existence. Of course, this is a very peculiar example. Even so, I think that this transformation can be interpreted as an experience of conversion that yields a faith state in James's sense.

Furthermore, the everyday context of this example resembles the theological view that we can find God in every detail. This is what Richard Kearney calls "epiphanies of the everyday." "94 Kearney argues "[a]gainst the Grand Metaphysical Systems that construed God in terms of formal universals and abstract essences" 95 and claims that we should focus instead on the "eschaton dwelling in each unique, material instant, no matter how lowly or profane." ${ }^{96}$ In terms of skepticism, I think that such an epiphany can occur if the shopkeeper contemplates the regress into which the investigation of the investigation is thrown. He can then recover from this skeptical uneasiness by acknowledging that his apples are just there even though he cannot ultimately secure this fact on his own, which turns this everyday phenomenon into a mystery and himself into a faith state that, in James's terms, imparts glory to the common objects of life. ${ }^{97}$

Although he did not explicitly say as much, I think that Wittgenstein aimed at such transformation and thus did what Kearney demands: "What if we could rediscover ourselves again face-to-face with the infinite in the infinitesimal? Touch the sacred enfolded in the seeds of ordinary things?" In addition, Kearney describes the epiphanies of the everyday in terms of an uneasiness and its solution: "Some breaking down or breaking away from our given lived experience is necessary, it seems, for a breakthrough to the meaning of that same experience, at another level,

\footnotetext{
${ }^{93}$ Ibid. In German, "Glaube" denotes both, "faith" and "belief." This is why Wittgenstein adds a clarification in parentheses. In English, he would have just asked "And can one talk of faith here?"

${ }^{94}$ Richard Kearney, "Epiphanies of the Everyday: Toward a Micro-Eschatology" in After God: Richard Kearney and the Religious Turn in Continental Philosophy, ed. John P. Manoussakis (New York NY: Fordham Univ. Press, 2006), pp. 3-20 at p. 3.

${ }^{95}$ Ibid., p. 4.

${ }^{96}$ Ibid.

${ }^{97}$ See above; James, p. 390.
} 
one where we may see and hear otherwise." $" 98$ If the shopkeeper contemplates the regress of the investigation of the investigation, this can break him away from his everyday experience, rendering the world uncanny. But when he recovers from the skeptical threat through a self-surrender that accepts the apples out of an attitude of acknowledgment, he might see them differently. As Kearney points out, this process can happen in a moment, in an "eschatological instant": "For the eschatological instant is the one (and it is potentially every moment) in which we receive the gift of the world anew. The same world, of course, but refigured." 99 Indeed, I think that the acceptance of the apples can occur like a Wittgensteinian switch of aspect in which the shopkeeper instantly acknowledges the groundlessness of the apples' existence and, thereby, receives the gift of the world anew. ${ }^{100}$ Jean-Philippe Narboux, for example, points out that the difference between the "plain" and the "philosophical" in Clarke's reading of skepticism can be understood as a respective switch of aspect, ${ }^{101}$ which certainly can be applied to the shopkeeper's case.

Finally, Steven Affeldt argues with references to Cavell that Wittgenstein's Philosophical Investigations aim at self-transformation just as Augustine's Confessions aim at conversion. ${ }^{102}$ More precisely: "The basic structure of conversion in Philosophical Investigations is identical to that in the Confessions; it involves relinquishing a fantasy of self-sufficiency and recognizing dependence upon a supporting and sustaining ground." ${ }^{103}$ Similarly, I have argued above with respect to $O n$ Certainty that Wittgenstein wants to transform us from our natural state, in which we take our fundamental beliefs to be objectively justified, to a state of acknowledgment that accepts the groundlessness of these beliefs. As I have pointed out with reference to the example of the shopkeeper, this includes a form of self-surrender. On Affeldt's reading, Augustine also converts through a form of self-surrender: "He does not make himself convert. Instead, in the moment of conversion he stops struggling and does nothing." "104 Affeldt also speaks of a moment here, but in addition he claims that, for Augustine, the conversion is not conclusively achieved in a single moment. It has to be understood as an ongoing practice. ${ }^{105}$ In fact, for Affeldt, this

${ }^{98}$ Kearney, p. 16.

${ }^{99}$ Ibid., p. 15.

${ }^{100}$ For Wittgenstein, a switch of aspect is a new way of seeing while the object does not change: "I see that it has not changed; and yet I see it differently. I call this experience "noticing an aspect",; "The expression of a change of aspect is an expression of a new perception and, at the same time, an expression of an unchanged perception," Ludwig Wittgenstein, Philosophical Investigations, trans. P.M.S. Hacker and Joachim Schulte (Oxford UK: Wiley-Blackwell, 2009), pp. 203, 206. As for the shopkeeper, the apples remain the same, but are perceived differently. Ray Monk emphasizes the life-changing power of this transformation: "[I]n the case of a philosophical Weltanschauung the consequence of a 'change of aspect' might be a change of life," Monk, p. 516.

${ }^{101}$ Jean-Philippe Narboux, "Thompson Clarke's Tightrope Walk," International Journal for the Study of Scepticism 4 (2014): 153-88 at p. 180. For Clarke's distinction, cf. the beginning of the first part of this paper.

${ }^{102}$ Steven G. Affeldt, "Being Lost and Finding Home: Philosophy, Confession, Recollection, and Conversion in Augustine's Confessions and Wittgenstein's Philosophical Investigations" in Wittgenstein Reading, ed. Sascha Bru, Wolfgang Huemer, and Daniel Steuer (Berlin: De Gruyter, 2013), pp. 5-22 at p. 15.

${ }^{103}$ Ibid., p. 17.

${ }^{104}$ Ibid., p. 16.

${ }^{105}$ Ibid. 
is crucial in order to understand Augustine's impact on Wittgenstein. ${ }^{106} \mathrm{He}$ argues "that for Wittgenstein, too, conversion is an ongoing practice. It is not completed in the moment of conversion but is repeated or re-enacted in each treatment of philosophical disorder. But this, in turn, means that for Wittgenstein philosophy is essentially this very practice of conversion." ${ }^{107}$ Correspondingly, Espen Dahl points out not only that Wittgenstein did not find final or lasting peace. ${ }^{108} \mathrm{He}$ also argues that for Cavell the stance of acknowledgment is not the end of the story: "There are homecomings and peace, but they are transitory moments - no stable stance or perennial philosophical position is provided." 109 In particular, according to Cavell, as Dahl puts it, our "ordinary conditions ... are always already in the grip of sceptical denial and ... need reconfirmation and renewed acknowledgment every day." "110 According to Dahl, this corresponds to faith and applies particularly to Luther: "And the same holds true, I would say, of our relation to God in faith: for Luther, faith also implies daily despair (Anfechtung) and daily conversion." ${ }^{111}$ Paul Standish points out in more secular terms that, for Cavell, "rebirth is recurrent, our education a continuing turning of our natural reactions.... In the eventual ordinary the crisis is not simply overcome: to return to the ordinary is to find an economy of living that incorporates and acknowledges this fragility and disturbance in the human condition." 112 This account perfectly describes the unstable human position that I related above to the doctrine of original sin and, equally, to the lesson of Pyrrhonian skepticism.

Accordingly, I think that this fragility and disturbance in the human condition is reflected in both skepticism and religiosity. For James, the "common nucleus" of religiosity is an uneasiness and its solution. In this part of the paper I briefly discussed different versions of skepticism, and I think that the "common nucleus" of these versions is the - albeit unstable - solution of the uneasiness of our epistemic predicament. James referred to objective forms of melancholy, and while religions deal with all kinds of melancholies, I think that the skeptical bewilderment can also be the starting point of an ongoing practice of self-transformation or conversion. Affeldt claims that there is a "substantive difference in that for Augustine the sustaining ground is God and for Wittgenstein it is the rough ground of our ordinary language and the forms of life held in language." ${ }^{113}$ But I will argue in the next part that both skepticism and religiosity deal with the finitude of the human condition and that, thus, this difference is not as substantive as Affeldt takes it to be.

${ }^{106}$ Ibid.

${ }^{107}$ Ibid., p. 21, cf. also p. 18.

${ }^{108}$ Dahl, Stanley Cavell, p. 25.

${ }^{109}$ Ibid., p. 26.

${ }^{110}$ Dahl, "Finitude and Original Sin," p. 510.

${ }^{111}$ Ibid.

${ }^{112}$ Paul Standish, "Education for Grown-Ups, A Religion for Adults: Skepticism and Alterity in Cavell and Levinas," Ethics and Education 2 (2007): 73-91 at p. 88.

${ }^{113}$ Affeldt, p. 17. 


\section{INEFFABILITY AND THE TRANSFORMATIVE EXPERIENCE OF FINITUDE}

The basic difference between skepticism and religiosity concerns the latter's reference to God. However, skepticism does deal with the problem of absolute objectivity, and I will now argue that skepticism and religiosity share the problem of the ineffability of the absolute. In particular, the skeptic demands an absolute standpoint, but this notion, according to quietist readings, is confused. Similarly, mysticism and negative theology claim that God is incomprehensibly withdrawn and cannot be coherently conceived. In the case of skepticism, quietist positions claim that the skeptical problem dissolves. ${ }^{114}$ In the case of negative theology, the whole point of religiosity seems to dissolve as well. This is what David Hume famously points out in his Dialogues when Cleanthes says about the mystics: "They are, in a word, atheists, without knowing it." 115 Against such dissolutionist readings, I will argue in what follows that the failure of the attempt to grasp God or the absolute standpoint can evoke epistemically transformative experiences that lead to a new way of being and seeing with respect to the finitude of the human condition. That said, I think the notion of God as well as the notion of the absolute standpoint can be interpreted as referring to the very same aspect of the human condition, which dismantles the abovementioned difference between skepticism and religiosity.

At the beginning of this paper's first part, I introduced the problem of skepticism with respect to the notion of an "absolute standpoint." In particular, I referred to the notion of the "view from nowhere" by Thomas Nagel. Now, in his discussion of skepticism, Nagel proposes to pursue the quest for absolute objectivity in terms of what he calls "self-transcendence," 116 but he also demonstrates the conceptual problems of the notion of the "view from nowhere." Nagel argues that the skeptic is demanding an absolute standard of objectivity, but that this standard is not even consistently thinkable. This standard would have to be a view from nowhere. But in order to be absolutely objective, its putative objectivity would have to be assessed by another view, which immediately leads into a regress of perspectives. This regress puts the whole concept of absolute objectivity into question. As Nagel puts it:

However often we may try to step outside of ourselves, something will have to stay behind the lens, something in us will determine the resulting picture, and this will give grounds for doubt that we are really getting any closer to reality. The idea of objectivity thus seems to undermine itself. The aim is to form a conception of

\footnotetext{
${ }^{114}$ For a more detailed discussion of quietist positions, cf., e.g., Stelios Virvidakis, "Varieties of Quietism," Philosophical Inquiry 30 (2008): 157-75. Recent attempts to dissolve skepticism can be found in Duncan Pritchard, Epistemic Angst: Radical Skepticism and the Groundlessness of Our Believing (Princeton UK: Princeton Univ. Press, 2016); Genia Schönbaumsfeld, The Illusion of Doubt (Oxford UK: Oxford Univ. Press, 2016); and Andrea Kern, Sources of Knowledge: On the Concept of a Rational Capacity for Knowledge (Cambridge MA: Harvard Univ. Press, 2017).

${ }^{115}$ David Hume, Dialogues concerning Natural Religion and Other Writings, ed. Dorothy Coleman (Cambridge UK: Cambridge Univ. Press, 2007), p. 36.

${ }^{116} \mathrm{Cf}$. Nagel, pp. $74-77$.
} 
reality which includes ourselves and our view of things among its objects, but it seems that whatever forms the conception will not be included by it. ${ }^{17}$

It is a fascinating tension in Nagel's book that he explores the idea of the traditional philosophical quest for objectivity by way of transcending ourselves while claiming at the same time that the metaphor of the view from nowhere cannot be understood literally: "The most familiar scene of conflict is the pursuit of objective knowledge, whose aim is naturally described in terms that, taken literally, are unintelligible: we must get outside of ourselves, and view the world from nowhere within it." 118 According to this argument, the problem is not that we cannot have the view from nowhere, but rather that the notion of the "view from nowhere" is not fully comprehensible in the first place.

A similar argument can be found in the resolute and therapeutic readings of Wittgenstein. According to those readings, Wittgenstein's philosophy elucidates performatively that certain philosophical concepts are sheer nonsense. This particularly applies to the concept of a view from nowhere, as Alice Crary points out. With respect to the concept of an external viewpoint on language, Crary summarizes the therapeutic readings of Wittgenstein by claiming that according to these readings, Wittgenstein's “fundamental aim is to get us to see that the point of view on language we aspire to or think we need to assume when philosophizing - a point of view on language as if outside from which we imagine we can get a clear view of the relation between language and the world - is no more than the illusion of a point of view." 119 Following this line of thought, it seems that the skeptical problem of absolute objectivity simply dissolves, since we do not even know what "absolute objectivity" is supposed to mean.

Similarly, negative theology's claim that God is incomprehensibly withdrawn leads to Hume's objection of atheism. As Hans Blumenberg puts it: "Every negative theology that revels in the realms of what cannot be said immediately draws upon itself the objection that really there is nothing that one needs to say or can say once one has described God as what is absolutely inaccessible." ${ }^{120}$ Nevertheless, elements of negative theology belong to almost every religion. In terms of philosophy, the claim that we cannot conceive of the absolute was discussed intensely in Neoplatonism. ${ }^{121}$ For Plotinus, although everything emanates from the One, the One itself is beyond being and cannot be grasped in thinking. However, there is a mystical experience of the One, the henosis, that is supposed to yield a certain form of experiential understanding that goes beyond thinking and is thus called hyper-noesis. The notion of an absolute that is beyond being and thinking but can be grasped experientially reasserts itself in a variety of guises throughout the centuries. In West-

\footnotetext{
${ }^{117}$ Ibid., p. 68.

${ }^{118}$ Ibid., p. 67.

${ }^{119}$ Crary, p. 6.

${ }^{120} \mathrm{Hans}$ Blumenberg, The Legitimacy of the Modern Age (Cambridge MA: The MIT Press, 1983), p. 490.

${ }^{121}$ Cf., e.g., Deirdre Carabine, The Unknown God: Negative Theology in the Platonic Tradition (Louvain: Wipf and Stock, 1995).
} 
ern Christianity, the most important authors are Pseudo-Dionysius the Areopagite, Meister Eckhart, John of the Cross, and Nicholas of Cusa. ${ }^{122}$ The latter famously claimed that although we cannot conceive of God, we still understand something about God through our non-understanding. Against Hume's claim that mysticism comes down to atheism, for Cusa, the failure to think God yields an experiential insight; it is a learned ignorance, a docta ignorantia. This form of understanding is linked to a new attitude, as Blumenberg points out: "But the Cusan's procedure sees an essential difference between muteness and falling silent. The language and system of metaphor that he developed for docta ignorantia do not represent a state of knowledge but a praxis, a method, a path to a certain sort of attitude."123

This kind of experiential understanding that is linked to a new attitude can be understood as the result of an experience that is not only personally, but also epistemically transformative by yielding a new way of being and seeing. ${ }^{124} \mathrm{In}$ the second part of this paper, I discussed the transformative aspect of skepticism and argued with reference to William James that this aspect is very close to the transformative experience of religious conversion. Now I will focus on the very peculiar experience of failing to think the absolute, be it God or the external standpoint.

On my reading, the experience of negative theology consists in the failure of the attempt to think the absolute and leads to the abandonment of this attempt, which is a form of surrender. Moreover, the experience of this surrender is epistemically transformative, since it yields a new way of seeing the world with respect to the incomprehensibility of the absolute. We still fail to think the absolute, but the experience of this failure does thus not end in sheer ignorance but in learned ignorance. As a matter of fact, Cusa's notion of "learned ignorance" describes a new way of seeing that is attained through the insight in God's incomprehensibility. ${ }^{125}$ On my reading, Cusa's concept of God "showing Godself to us as incomprehensible"126 is best understood as a reference to the epistemically transformative experience of the failure to think God.

When Cusa establishes the notion of learned ignorance, he refers to a similar argument in the Guide for the Perplexed by the important Jewish exponent of negative theology, Maimonides, who states that "apprehension of Him consists in the inability to attain the ultimate term in apprehending Him." ${ }^{127}$ In his book on Maimonides Josef Stern discusses the respective arguments in the Guide and analyzes

${ }^{122}$ Cf., e.g., Denys Turner, The Darkness of God: Negativity in Christian Mysticism (Cambridge UK: Cambridge Univ. Press, 1995).

${ }^{123}$ Blumenberg, p. 490.

${ }^{124}$ This link between personally and epistemically transformative experience is discussed by L. A. Paul in her famous book on decision theory, cf. Laurie A. Paul, Transformative Experience (Oxford UK: Oxford Univ. Press, 2014), pp. 5-15.

${ }^{125}$ Nicholas of Cusa, Selected Spiritual Writings, trans. H. Lawrence Bond (New York NY: Paulist Press, 1997), p. 91.

${ }^{126}$ Ibid., p. 127.

${ }^{127}$ Maimonides, Guide for the Perplexed, trans. Shlomo Pines (Chicago IL: Univ. of Chicago Press, 1963), p. 139. Nicholas de Cusa refers to this very passage, cf. Cusa, p. 107. 
the transformative experience of failing to think God against this background. ${ }^{128}$ Moreover, he draws a connection to Pyrrhonism in this respect. ${ }^{129}$ In particular, he points out that the skeptic deals with the equipollence of contradictory propositions and argues that Maimonides faces in a similar way antinomies with respect to God. ${ }^{130} \mathrm{He}$ refers to the skeptic's suspension of judgment and to the following state of ataraxia and claims that Maimonides aims at a new state of mind that "parallels the classical skeptic's goal of happiness." ${ }^{31}$ According to Stern, this is a "state of divine worship into which Maimonides has put himself through his self-refuting reasoning about God, states induced by his skeptical 'acknowledgment' of his inability to have knowledge of God." ${ }^{32}$ This certainly is a transformative experience of self-surrender with respect to the incomprehensibility of God, which Stern describes with respect to Pyrrhonism in more detail as follows:

Recall the Pyrrhonist who finally achieves happiness, which he originally sought to reach through the acquisition of knowledge, by instead suspending judgment at the point of isostheneia. So Maimonides achieves worship of God, which he began his inquiry thinking he would achieve only by positive knowledge, instead through recognition of his inability to acquire that knowledge. In reaching the point of acquiescing to the fact that he can have no knowledge about God, Maimonides finds himself in awe and worship of the deity, in a state in which he cannot but exclaim his praise or dazzlement. ${ }^{133}$

Against this background, I want to suggest that the failure to think the absolute standpoint of objectivity likewise leads to a new way of being and seeing. Accordingly, on my reading, the experience of failing to think the absolute, be it God or the absolute standpoint, is epistemically transformative, since it yields a new way of seeing the world with respect to the incomprehensibility of the absolute. I thus think that skepticism, understood as a practice of self-transformation, resembles negative theology in yielding a form of learned ignorance that goes beyond a quietist dissolution. As a consequence, I want to suggest that both the religious language game of God (at least in the context of mysticism and negative theology) and the philosophical language game of the absolute standpoint can be interpreted as referring to such transformative experience.

Even more, I think that they refer to the same experience of failing to step outside what Thompson Clarke called the "plain." As I argued in this paper's first part, it is only through the unfulfillable and thus perpetual attempt to step outside the plain that we understand what it means to be "plain," and I think that the language game

${ }^{128}$ Josef Stern, The Matter and Form of Maimonides' Guide (Cambridge MA: Harvard Univ. Press, 2013), pp. 244-45.

${ }^{129}$ Ibid., pp. 86, 146-48, 244-49.

${ }^{130}$ Ibid., p. 244.

${ }^{131}$ Ibid. Of course, the skeptic's goal is ataraxia. However, ataraxia and eudaimonia were often closely related in Hellenistic philosophy.

${ }^{132}$ Ibid., p. 246.

${ }^{133}$ Ibid., cf. also p. 148. 
of skepticism and the religious language game are just different ways of articulating this aspect of our humanity, be it in terms of the absolute standpoint, in terms of God, or in terms of our finitude.

\section{CONCLUSION: THE COMMON CORE OF PHILOSOPHY AND RELIGION}

To sum up, although they use different language games, I think that skepticism and religiosity deal in their respective ways with the finitude of the human condition. This can be seen, for example, in the analogies between Cavell's reading of skepticism and the doctrine of original sin that I discussed in the first part and in the parallels between skeptical transformation and religious conversion that I highlighted in the second part. Moreover, the notion of "God" as well as the notion of the "absolute standpoint" are incomprehensible, and in both cases, the respective language game is best understood as referring to the transformative experience of failing to think the absolute, which I demonstrated in the third part. Not least, religion and philosophy can evoke such experiences. Josef Stern, for example, argues that Maimonides wanted his readers to share his experience: "One aim of the Guide is to guide the reader to experience for himself the experience Maimonides depicts." 134 Similarly, Cavell claims that it was part of Wittgenstein's teaching to evoke experiences of this kind. ${ }^{135}$ In sum, I have argued that we know only through the transformative experience of failing to think the absolute what it means to be plain or finite. Skeptical transformation and religious conversion both imply a crisis of surrender that overcomes the attempt to transcend our plain condition by accepting that we do not and cannot attain a full grasp of our existence. This may sound terrifying, but can eventually lead to an attitude of acknowledgment or to James's faith state or, as I put it, to a reliant stance of humility and equanimity. Either way, it is only through such a transformation of attitude that we understand, albeit experientially, that we are finite beings.

Furthermore, although I think that the finitude of the human condition can thus be experientially understood, this does not provide a stable, permanent state of peace of mind. Instead, the philosophical and religious struggle with this finitude is an ongoing, potentially endless, task that indeed requires equanimity. As I argued in the second part, for Sextus, Wittgenstein, and Cavell, the transformative practice of skepticism does not come to an end. With reference to Pyrrhonism, Josef Stern argues that Maimonides's negative approach to God is an endless task too: "[T]he skeptic is one who persistently engages in inquiry without end, despite the fact that he never reaches the destination of knowledge. Maimonides is proposing to his reader that he engage himself in such inquiry." ${ }^{136}$ Also, Nicholas of Cusa did not present an ultimate version of his negative approach to God, but established

\footnotetext{
${ }^{134}$ Ibid., p. 293.

${ }^{135}$ Cavell, Claim of Reason, p. 15.

${ }^{136}$ Stern, p. 294.
} 
more and more accounts. In his abovementioned critique of Pyrrhonism, Markus Gabriel claims that contrary to the endless skeptical practice, the vision of the One in Plotinus comes to a final state of rest. ${ }^{137}$ However, Deirdre Carabine argues that "since God is infinite, the quest must also be infinite." 138 It might be possible to interpret him otherwise, but I am certain that this applies to Plotinus as well. As Stephen Mulhall puts it: "The best way to appreciate the transcendence of God to human language is thus not to fall into silence ... ; it is rather endlessly to employ that language in relation to him, and endlessly to experience its inevitable collapse upon itself. Religious language is thus essentially self-subverting language." ${ }^{139}$ Not least, on my reading, this also pertains to the language game of philosophy that tries to articulate the plain human condition. Since we understand our plain condition only through the unachievable attempt to step outside the plain, the task of articulating this aspect of the human condition is an equally endless quest.

Of course, although the experience of the skeptical regress can be interpreted as a religious experience, there are many more, different kinds of religious experience. I still think, however, that at the heart of religion as well as philosophy there lies a profound concern with our plainness or finitude, a concern that can thus be understood as a common core of philosophy and religion. Against the background of the ineffability of the absolute, the endless task of philosophy and religion is to reveal our finitude through transformative experiences. Thus, I refer to more than just a structural analogy when I speak of the religious dimension of skepticism. ${ }^{140}$

${ }^{137}$ Gabriel, p. 293.

${ }^{138}$ Carabine, p. 256.

${ }^{139}$ Stephen Mulhall, The Great Riddle: Wittgenstein and Nonsense, Theology and Philosophy (Oxford UK: Oxford Univ. Press, 2015), p. 59.

${ }^{140}$ I want to thank Oren Hanner, Jeff Kochan, Andrew Lugg, Stephen Mulhall, Hans Julius Schneider, and Genia Schönbaumsfeld for their helpful comments on an earlier version of the article. Over and above, I am much obliged to Roger Eichorn for his comprehensive treatment of this paper. 